Article

\title{
Magnetic and Electrochemical Properties of Lantern-Type Dinuclear Ru(II,III) Complexes with Axial Chloride Ions or Water Molecules
}

\author{
Makoto Handa ${ }^{1, *(\mathbb{D}}$, Haruki Yairi ${ }^{1}$, Natsumi Yano ${ }^{1}$, Minoru Mitsumi ${ }^{2}$, Hiroshi Sakiyama ${ }^{3}$ (D), \\ Masaharu Kitashima ${ }^{4}$, Kazuhito Inoue ${ }^{4}$, Ryoji Mitsuhashi ${ }^{5}$ (D), Masahiro Mikuriya ${ }^{5}$, \\ Haruo Akashi ${ }^{6}$ and Yusuke Kataoka ${ }^{1, *}$ \\ 1 Department of Chemistry, Graduate School of Natural Science and Technology, Shimane University, \\ 1060 Nishikawatsu, Matsue 690-8504, Japan; s179225@matsu.shimane-u.ac.jp (H.Y.); \\ s179802@matsu.shimane-u.ac.jp (N.Y.) \\ 2 Department of Chemistry, Faculty of Science, Okayama University of Science, 1-1 Ridaicho, \\ Kita-Ku, Okayama 700-0005, Japan; mitsumi@chem.ous.ac.jp \\ 3 Department of Science, Faculty of Science, Yamagata University, \\ 1-4-12 Kojirakawa, Yamagata 990-8560, Japan; saki@sci.kj.yamagata-u.ac.jp \\ 4 Department of Biological Sciences, Faculty of Science, Kanagawa University, Hiratsuka, \\ Kanagawa 259-1293, Japan; pt125536zy@jindai.jp (M.K.); inoue-bio@kanagawa-u.ac.jp (K.I.) \\ 5 Department of Applied Chemistry for Environment, School of Science and Technology, \\ Kwansei Gakuin University, 2-1 Gakuen, Sanda 669-1337, Japan; mitsuhashi@kwansei.ac.jp (R.M.); \\ junpei@kwansei.ac.jp (M.M.) \\ 6 Research Institute of Natural Sciences, Okayama University of Science, 1-1 Ridai-cho, \\ Kita-ku, Okayama 700-0005, Japan; akashi@rins.ous.ac.jp \\ * Correspondence: handam@riko.shimane-u.ac.jp (M.H.); kataoka@riko.shimane-u.ac.jp (Y.K.); \\ Tel.: +81-852-32-6418 (M.H.); +81-852-32-6413 (Y.K.)
}

Received: 31 December 2018; Accepted: 25 February 2019; Published: 6 March 2019

\begin{abstract}
By using $\left[\mathrm{Ru}_{2}\left(\mathrm{O}_{2} \mathrm{CC}_{3} \mathrm{H}_{7}\right)_{4} \mathrm{Cl}\right]_{n}$ (1) as a starting material, ${ }^{n} \mathrm{Bu}_{4} \mathrm{~N}\left[\mathrm{Ru}_{2}\left(\mathrm{O}_{2} \mathrm{CC}_{3} \mathrm{H}_{7}\right)_{4} \mathrm{Cl}_{2}\right]$ $\left({ }^{n} \mathrm{Bu}_{4} \mathrm{~N}^{+}=\right.$tetra(n-butyl)ammonium cation) (2) and $\left[\mathrm{Ru}_{2}\left(\mathrm{O}_{2} \mathrm{CC}_{3} \mathrm{H}_{7}\right)_{4}\left(\mathrm{H}_{2} \mathrm{O}\right)_{2}\right] \mathrm{BF}_{4}(3)$ were prepared. The lantern-type dinuclear structures with axial chloride ions or water molecules were confirmed for $\mathbf{2}$ and $\mathbf{3}$ by X-ray crystal structure analyses. The crystal structures of $\mathbf{2}$ and $\mathbf{3}$ were compared with that of $\mathbf{1}$. In the crystal of $\mathbf{2}$, there were three crystallographically different dinuclear units; the Ru-Ru distances of each unit were 2.3094(3), 2.3046(4), and 2.3034(4) $\AA$, respectively, which were longer than those of 1 (2.281(4) $\AA$ ) and 3 (2.2584 (7) $\AA$ ). Temperature dependent magnetic susceptibility measurements were performed for 1 and $\mathbf{2}$ as well as 3 . The effective magnetic moments $\left(\mu_{\text {eff }}\right)$ at $300 \mathrm{~K}$ were 3.97 (for 1), 4.00 (for 2), and $3.97 \mu_{\mathrm{B}}$ (for 3), respectively. The decreases in the $\mu_{\mathrm{eff}}$ value were confirmed for all of the complexes due to the large zero-field splitting $(D): D=68 \mathrm{~cm}^{-1}$ for $1,78 \mathrm{~cm}^{-1}$ for 2, and $60 \mathrm{~cm}^{-1}$ for 3. Cyclic voltammograms measured in $\mathrm{CH}_{2} \mathrm{Cl}_{2}$ with a electrolyte of ${ }^{n} \mathrm{Bu}_{4} \mathrm{~N}\left(\mathrm{BF}_{4}\right)$ showed the $\mathrm{Ru}_{2}{ }^{5+} / \mathrm{Ru}_{2}{ }^{4+}$ process at $-0.2--0.4 \mathrm{~V}$ (vs. SCE) and the $\mathrm{Ru}_{2}{ }^{6+} / \mathrm{Ru}_{2}{ }^{5+}$ one at $1.3-1.4 \mathrm{~V}$ (vs. $\mathrm{SCE})$, of which potentials were confirmed by the DFT calculation for ${ }^{n} \mathrm{Bu}_{4} \mathrm{~N}\left[\mathrm{Ru}_{2}\left(\mathrm{O}_{2} \mathrm{CC}_{3} \mathrm{H}_{7}\right)_{4} \mathrm{Cl}_{2}\right]$.
\end{abstract}

Keywords: lantern-type diruthenium(II,III) complex; butanoato-bridge; crystal structures; magnetic properties; electrochemical properties; DFT calculation

\section{Introduction}

There has been much interest devoted to lantern-type dinuclear complexes with a direct metal-metal (M-M) interaction giving a wide range of remarkable physical-chemical properties based on the direct $\mathrm{M}-\mathrm{M}$ interaction [1-5]. In the case of the ruthenium dinuclear complexes, the crystal 
structure was first reported in 1969 by Cotton and co-workers for $\left[\mathrm{Ru}_{2}\left(\mathrm{O}_{2} \mathrm{CC}_{3} \mathrm{H}_{7}\right)_{4} \mathrm{Cl}\right]_{n}(\mathbf{1})$, where the mixed-valent diruthenium(II,III) dinuclear $\left(\mathrm{Ru}_{2}{ }^{5+}\right)$ units are linked by axial chloride ions to give a zig-zag chain structure with a $\mathrm{Ru}-\mathrm{Cl}_{\mathrm{ax}}-\mathrm{Ru}$ bond angle of $125.4^{\circ}$, as shown in Scheme 1 [6].

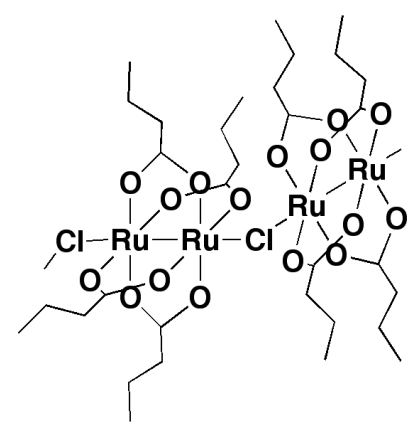

Scheme 1. Chain structure of $\left[\mathrm{Ru}_{2}\left(\mathrm{O}_{2} \mathrm{CC}_{3} \mathrm{H}_{7}\right)_{4} \mathrm{Cl}\right]_{n}$.

Temperature-dependent magnetic susceptibility was later reported for $\left[\mathrm{Ru}_{2}\left(\mathrm{O}_{2} \mathrm{CC}_{3} \mathrm{H}_{7}\right)_{4} \mathrm{Cl}\right]_{n}(\mathbf{1})$ by Telser et al., showing a large zero-field splitting $\left(D=76.8 \mathrm{~cm}^{-1}\right)$ with $g=2.10$ with the support of EPR (electron paramagnetic resonance) spectral data [7]. In the study, they did not mention the interaction through the axial $\mathrm{Cl}^{-}$ions between the paramagnetic dinuclear units $(S=3 / 2)$, although we have lately described the importance of the axial bond through interaction to understand the magnetic behaviors of the polymer complexes of $\mathrm{Ru}_{2}{ }^{5+}$ units linked by axial ligands [5]. An electrochemical study has been also performed for $\left[\mathrm{Ru}_{2}\left(\mathrm{O}_{2} \mathrm{CC}_{3} \mathrm{H}_{7}\right)_{4} \mathrm{Cl}\right]_{n}$ (1); the complicated electrochemical behaviors found in CV (cyclic voltammogram) with two redox waves for $\mathrm{Ru}_{2}{ }^{5+} / \mathrm{Ru}_{2}{ }^{4+}$ at $E_{1 / 2}=0.00 \mathrm{~V}$ (vs. SCE) and $-0.34 \mathrm{~V}$ (vs. SCE) in dichloromethane containing $0.1 \mathrm{M}$ tetrabutylammonium perchlorate $\left({ }^{n} \mathrm{Bu}_{4} \mathrm{~N}\left(\mathrm{ClO}_{4}\right)\right)$ were interpreted in terms of equilibrium $\left[\mathrm{Ru}_{2}\left(\mathrm{O}_{2} \mathrm{CC}_{3} \mathrm{H}_{7}\right)_{4}\right]^{+}+n \mathrm{Cl}^{-} \leftrightarrow\left[\mathrm{Ru}_{2}\left(\mathrm{O}_{2} \mathrm{CC}_{3} \mathrm{H}_{7}\right)_{4} \mathrm{Cl}_{n}\right]^{(n-1)-}$ [8]. That is, the $\mathrm{Ru}_{2}{ }^{5+} / \mathrm{Ru}_{2}{ }^{4+}$ redox waves were observed at $E_{1 / 2}=0.00 \mathrm{~V}$ for $\left[\mathrm{Ru}_{2}\left(\mathrm{O}_{2} \mathrm{CC}_{3} \mathrm{H}_{7}\right)\right]^{+}$and $-0.34 \mathrm{~V}$ for $\left\{\mathrm{Ru}_{2}\left(\mathrm{O}_{2} \mathrm{CC}_{3} \mathrm{H}_{7}\right)_{4} \mathrm{Cl}_{n}\right\}\left({ }^{n-1}\right)^{-}$, respectively. The axial coordination of chloride ions is considered to magnetically and electrochemically affect the properties of the $\mathrm{Ru}_{2}{ }^{5+}$ complexes. However, systematic investigation has not been conducted by changing the number of axial chloride ions. In this study, the dinuclear complexes ${ }^{n} \mathrm{Bu}_{4} \mathrm{~N}\left[\mathrm{Ru}_{2}\left(\mathrm{O}_{2} \mathrm{CC}_{3} \mathrm{H}_{7}\right)_{4} \mathrm{Cl}_{2}\right](2)$ and $\left[\mathrm{Ru}_{2}\left(\mathrm{O}_{2} \mathrm{CC}_{3} \mathrm{H}_{7}\right)_{4}\left(\mathrm{H}_{2} \mathrm{O}\right)_{2}\right] \mathrm{BF}_{4}(3)$ were prepared, characterized, and compared with $\left[\mathrm{Ru}_{2}\left(\mathrm{O}_{2} \mathrm{CC}_{3} \mathrm{H}_{7}\right)_{4} \mathrm{Cl}\right]_{n}$ (1) for their crystal structures, magnetic properties, and electrochemical properties. Furthermore, DFT calculations were also performed to estimate the redox potentials for the $\mathrm{Ru}_{2}{ }^{5+}$ complexes.

\section{Results and Discussion}

\subsection{Synthesis and Characterizations}

The addition of an excess amount of ${ }^{n} \mathrm{Bu}_{4} \mathrm{NCl}$ to the dinuclear units of $\left[\mathrm{Ru}_{2}\left(\mathrm{O}_{2} \mathrm{CC}_{3} \mathrm{H}_{7}\right)_{4} \mathrm{Cl}\right]_{n}$ (1) with stirring at room temperature for $24 \mathrm{~h}$ in dichloromethane solution gave a dichloridodiruthenium(II,III) complex ${ }^{n} \mathrm{Bu}_{4} \mathrm{~N}\left[\mathrm{Ru}_{2}\left(\mathrm{O}_{2} \mathrm{CC}_{3} \mathrm{H}_{7}\right)_{4} \mathrm{Cl}_{2}\right]$ (2) with a yield of $85 \%$ (based on $\mathrm{Ru}_{2}{ }^{5+}$ unit of $\left.\mathbf{1}\right)$. On the other hand, the axial chloride ligand of $\mathbf{1}$ could be removed by the reaction with $\mathrm{AgBF}_{4}$ in $\mathrm{THF}$ at room temperature for $24 \mathrm{~h}$ with stirring to give a diaquadiruthenium(II,III) complex $\left[\mathrm{Ru}_{2}\left(\mathrm{O}_{2} \mathrm{CC}_{3} \mathrm{H}_{7}\right)_{4}\left(\mathrm{H}_{2} \mathrm{O}\right)_{2}\right] \mathrm{BF}_{4}$ (3) with a yield of $69 \%$. Their chemical formula were confirmed by elemental analyses. The IR spectra of 2 and 3 showed the $\mathrm{COO}$ vibrations as a set of two distinctive bands ( $v_{\text {asym }}(\mathrm{COO}) 1465 \mathrm{~cm}^{-1}$ and $v_{\text {sym }}$ (COO) $1426 \mathrm{~cm}^{-1}$ for $2 ; v_{\text {asym }}$ (COO) $1455 \mathrm{~cm}^{-1}$ and $v_{\text {sym }}$ (COO) $1428 \mathrm{~cm}^{-1}$ for 3 ) in a similar energy region to those of $1\left(v_{\mathrm{asym}}\right.$ (COO) $1462 \mathrm{~cm}^{-1} \mathrm{and} v_{\mathrm{sym}}$ (COO) $1425 \mathrm{~cm}^{-1}$ ). These facts suggest that the dinuclear skeleton is preserved in the above-mentioned reactions to 2 and 3. The stretching vibrations of $\mathrm{BF}_{4}{ }^{-}$appear as a broad band around $1090 \mathrm{~cm}^{-1}$ in 3 , which indicate no coordination of the ion to the $\mathrm{Ru}_{2}{ }^{5+}$ core [9]. 


\subsection{Crystal Structures}

Crystals of $\mathbf{2}$ and $\mathbf{3}$ suitable for X-ray crystal structure analyses were obtained by recrystallizations from dichloromethane-diethyl ether and dichloromethane-benzene mixed solvents, respectively. The crystal packing diagram of ${ }^{n} \mathrm{Bu}_{4} \mathrm{~N}\left[\mathrm{Ru}_{2}\left(\mathrm{O}_{2} \mathrm{CC}_{3} \mathrm{H}_{7}\right)_{4} \mathrm{Cl}_{2}\right]$ (2) is shown in Figure 1 . In this crystal, there are crystallographically different dinuclear $(\mathrm{Cl}-\mathrm{Ru}-\mathrm{Ru}-\mathrm{Cl})$ anionic units designated as $(\mathrm{Cl1}-\mathrm{Ru} 1-\mathrm{Ru} 2-\mathrm{Cl} 2),\left(\mathrm{Cl} 3-\mathrm{Ru} 3-\mathrm{Ru}^{\prime \prime}-\mathrm{Cl}^{\prime \prime}\right)$, and $\left(\mathrm{Cl} 4-\mathrm{Ru} 4-\mathrm{Ru}^{\prime \prime \prime}-\mathrm{Cl}^{\prime \prime \prime}\right)$, respectively, while ${ }^{n} \mathrm{Bu}_{4} \mathrm{~N}^{+}$ counter cations exist among the $(\mathrm{Cl}-\mathrm{Ru}-\mathrm{Ru}-\mathrm{Cl})^{-}$anionic units without any important short contacts with the $(\mathrm{Cl}-\mathrm{Ru}-\mathrm{Ru}-\mathrm{Cl})$ units in the crystal. The crystallographical inversion centers are located at the centers of the (Cl3-Ru3- $\left.\mathrm{Ru}^{\prime \prime}-\mathrm{Cl}^{\prime \prime}\right)$ and $\left(\mathrm{Cl} 4-\mathrm{Ru} 4-\mathrm{Ru} 4^{\prime \prime \prime}-\mathrm{Cl}_{4}{ }^{\prime \prime \prime}\right)$ dinuclear units. The ORTEP drawing for one of the anionic dinuclear units, (Cl1-Ru1-Ru2-Cl2), is depicted in Figure 2. Including the other dinuclear units, $\left(\mathrm{Cl} 3-\mathrm{Ru} 3-\mathrm{Ru}^{\prime \prime}-\mathrm{Cl}^{\prime \prime}\right)$ and $\left(\mathrm{Cl} 4-\mathrm{Ru} 4-\mathrm{Ru} 4^{\prime \prime \prime}-\mathrm{Cl} 4^{\prime \prime \prime}\right)$, of which structures are shown in Figures S1 and S2, respectively, the lantern-type dinuclear structures with axial chloride ligands are basically the same as those reported for ${ }^{n} \mathrm{Bu}_{4} \mathrm{~N}\left[\mathrm{Ru}_{2}\left(\mathrm{O}_{2} \mathrm{CCH}_{3}\right)_{4} \mathrm{Cl}_{2}\right]$ (4) [10]. The $\mathrm{Ru}-\mathrm{Ru}$ and $\mathrm{Ru}-\mathrm{Cl}^{\mathrm{ax}}$ bond distances were 2.3094(3) (for Ru1-Ru2), 2.3046(4) (for Ru3-Ru3"), 2.3034(4) $\AA$ (Ru4-Ru4 ${ }^{\prime \prime \prime}$ ), 2.5344(6) (for Ru1-Cl1), 2.5524(6) (for Ru2-Cl2), 2.5335(6) (for Ru3-Cl3), and 2.5127(6) $\AA$ (for $\mathrm{Ru} 4-\mathrm{Cl} 4$ ), respectively. The $\mathrm{Ru}-\mathrm{Ru}$ and $\mathrm{Ru}-\mathrm{Cl}$ bond distances were similar to those for $4\left(\mathrm{Ru}-\mathrm{Ru}=2.3019(4)\right.$ and 2.3006(5) $\AA$; $\mathrm{Ru}-\mathrm{Cl}^{\mathrm{ax}}=2.5316(6)$ and 2.5181(7) $\AA$ ). The $\mathrm{Ru}-\mathrm{Ru}$ bond distances of $\mathbf{2}$ seemed to be large when compared with that of $\mathbf{1}(2.281(4) \AA)$, while the $\mathrm{Ru}-\mathrm{Cl}^{\mathrm{ax}}$ distances of 2 were rather small when compared with that of 1 (2.587(5) $\AA$ ). The ORTEP drawing of the cationic unit of $\left[\mathrm{Ru}_{2}\left(\mathrm{O}_{2} \mathrm{CC}_{3} \mathrm{H}_{7}\right)_{4}\left(\mathrm{H}_{2} \mathrm{O}\right)_{2}\right] \mathrm{BF}_{4}(3)$ is depicted in Figure 3. The crystallographic inversion center exists at the center of the lantern-type dinuclear $\mathrm{Ru}_{2}{ }^{5+}$ core. The Ru1-Ru1' and Ru1-O5 bond distances were 2.2584(7) and 2.267(3) $\AA$, respectively, which were comparable to the corresponding distances for the previously reported lantern-type $\mathrm{Ru}_{2}{ }^{5+}$ complexes with axial water molecules, $\left[\mathrm{Ru}_{2}\left(\mathrm{O}_{2} \mathrm{CCH}_{3}\right)_{4}\left(\mathrm{H}_{2} \mathrm{O}\right)_{2}\right] \mathrm{BF}_{4}\left(\mathrm{Ru}-\mathrm{Ru}=2.248(1) \AA\right.$ and $\mathrm{Ru}-\mathrm{O}^{\mathrm{ax}}=2.34(1)$ and 2.27(1) $\AA$ ) [11], $\left[\mathrm{Ru}_{2}\left(\mathrm{O}_{2} \mathrm{CCH}_{3}\right)_{4}\left(\mathrm{H}_{2} \mathrm{O}\right)_{2}\right] \mathrm{PF}_{6} \bullet 3 \mathrm{H}_{2} \mathrm{O}\left(\mathrm{Ru}-\mathrm{Ru}=2.2648(9) \AA\right.$ and $\left.\mathrm{Ru}-\mathrm{O}^{\mathrm{ax}}=2.279(4) \AA\right)$ [12], $\left[\mathrm{Ru}_{2}\left\{\mathrm{O}_{2} \mathrm{CC}\left(\mathrm{CH}_{3}\right)_{3}\right\}_{4}\left(\mathrm{H}_{2} \mathrm{O}\right)_{2}\right] \mathrm{BF}_{4}\left(\mathrm{Ru}-\mathrm{Ru}=2.259(1) \AA\right.$ and $\mathrm{Ru}-\mathrm{O}^{\mathrm{ax}}=2.280(5)$ and 2.323(5) $\AA$ ), and $\left[\mathrm{Ru}_{2}\left\{\mathrm{O}_{2} \mathrm{CC}\left(\mathrm{CH}_{3}\right)_{3}\right\}_{4}\left(\mathrm{H}_{2} \mathrm{O}\right)_{2}\right] \mathrm{BF}_{4} \bullet \mathrm{CH}_{2} \mathrm{Cl}_{2}\left(\mathrm{Ru}-\mathrm{Ru}=2.256(1) \AA\right.$ and $\mathrm{Ru}-\mathrm{O}^{\mathrm{ax}}=2.330(5)$ and $2.248(4)$ $\AA$ ) [13]. As depicted in the crystal packing diagram (Figure 4), the $\mathrm{BF}_{4}{ }^{-}$counter anions are located among the dinuclear $\mathrm{Ru}_{2}{ }^{5+}$ units without any important contacts between them. Alternatively, there are hydrogen bonds between an axially coordinating water molecule and a bridging butanoate oxygen within the neighboring dinuclear unit as shown by dashed line $\left(\mathrm{O} 5-\mathrm{O} 3{ }^{\prime \prime}=2.800 \AA\right)$ in Figure 4 where the hydrogen bonds connect to $\mathrm{Ru}_{2}{ }^{5+}$ to give a zig-zag chain. This is in contrast to the hydrogen bonds between the axially coordinated water molecules and $\mathrm{BF}_{4}{ }^{-}$anions that were found for $\left[\mathrm{Ru}_{2}\left\{\mathrm{O}_{2} \mathrm{CC}\left(\mathrm{CH}_{3}\right)_{3}\right\}_{4}\left(\mathrm{H}_{2} \mathrm{O}\right)_{2}\right] \mathrm{BF}_{4}$ and $\left[\mathrm{Ru}_{2}\left\{\mathrm{O}_{2} \mathrm{CC}\left(\mathrm{CH}_{3}\right)_{3}\right\}_{4}\left(\mathrm{H}_{2} \mathrm{O}\right)_{2}\right] \mathrm{BF}_{4} \bullet \mathrm{CH}_{2} \mathrm{Cl}\left(\mathrm{O}\right.$ (water) $-\mathrm{F}\left(\mathrm{BF}_{4}^{-}\right)$ $=2.742 \sim 2.960 \AA$ ), leading to two-dimensional sheets [13]. 


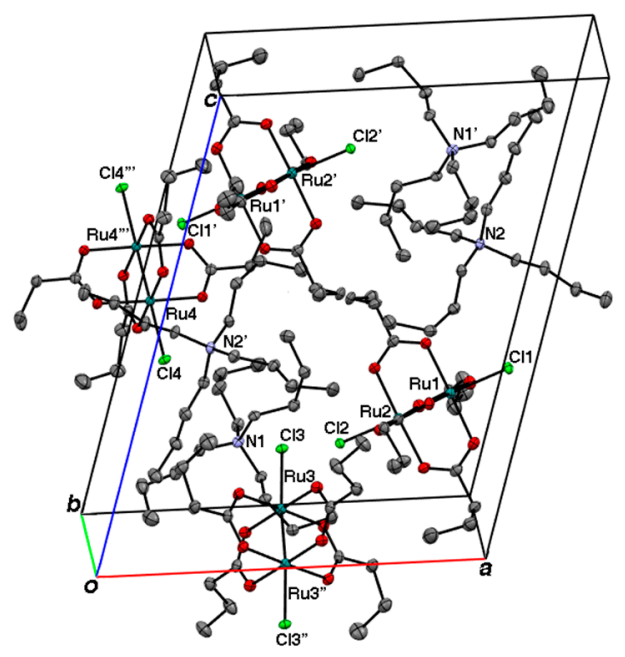

Figure 1. Packing diagram of 2. Primes $\left({ }^{\prime}\right)$, double primes $\left(^{\prime \prime}\right)$, and triple primes $\left(^{\prime \prime \prime}\right)$ refer to the equivalent positions $(1-\mathrm{x}, 1-\mathrm{y}, 1-\mathrm{z}),(-\mathrm{x},-1-\mathrm{y},-\mathrm{z})$, and $(-\mathrm{x}, 2-\mathrm{y}, 1-\mathrm{z})$, respectively.

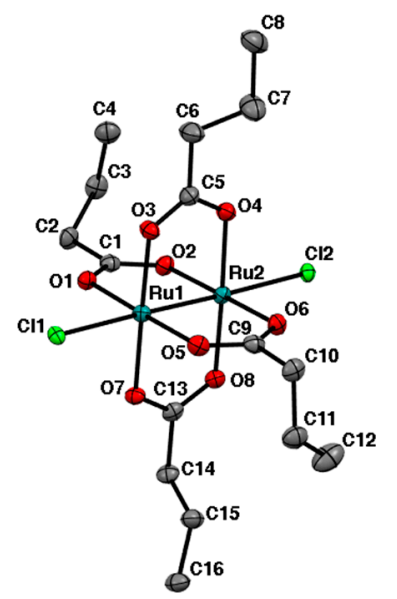

Figure 2. Structure of an anionic dinuclear unit designated as (Cl1-Ru1-Ru2-Cl2). Hydrogen atoms were omitted for clarity. The thermal ellipsoids are shown at the 50\% probability level.



Figure 3. Structure of the cationic dinuclear unit of $\left[\mathrm{Ru}_{2}\left(\mathrm{O}_{2} \mathrm{CC}_{3} \mathrm{H}_{7}\right)_{4}\left(\mathrm{H}_{2} \mathrm{O}\right)_{2}\right] \mathrm{BF}_{4}(3)$. Hydrogen atoms were omitted for clarity. Primes $(')$ refer to the equivalent positions $(-\mathrm{x},-\mathrm{y},-\mathrm{z})$. The thermal ellipsoids are shown at the $50 \%$ probability level. 


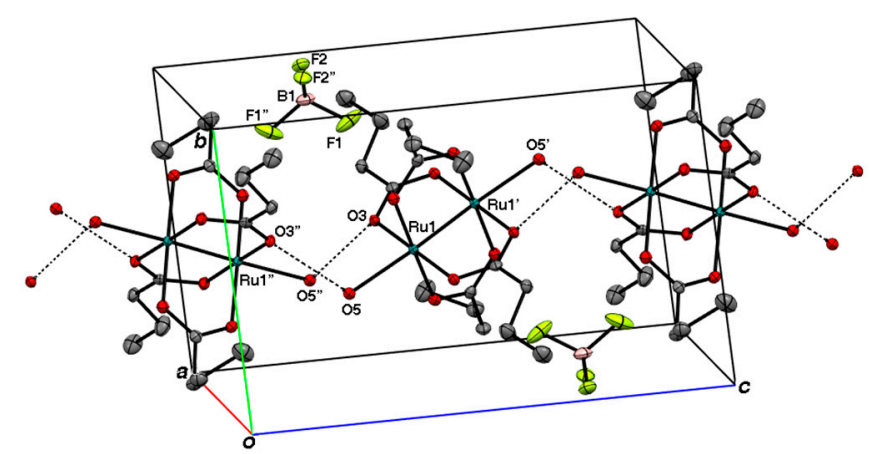

Figure 4. Packing diagram of 3. Primes $\left(^{\prime}\right)$ and double primes (") refer to the equivalent positions $(-x$, $-\mathrm{y},-\mathrm{z})$ and $(-\mathrm{x}, \mathrm{y}, 1 / 2-\mathrm{z})$, respectively.

\subsection{Magnetic Properties}

The temperature dependences of magnetic susceptibilities and effective magnetic moments of $\mathbf{1 , 2}$, and 3 are shown in Figures 5-7, respectively. The magnetic moments at 300 K were 3.97 (for 1), 4.00 (for 2), and $3.97 \mu_{\mathrm{B}}$ (for 3), respectively, indicating the existence of three unpaired electrons within the dinuclear $\mathrm{Ru}_{2}{ }^{5+}$ cores like the other lantern-type tetrakis(carboxylato)diruthenium(II,III) with a formal electron configuration of $\sigma^{2} \pi^{4} \delta^{2}\left(\delta^{*} \pi^{*}\right)^{3}$ (i.e., $S=3 / 2$ ground state) [1]. All of the complexes showed decreases in the moments by lowering the temperature due to the strong zero-field splitting $(D)$. The magnetic behaviors were simulated using the Equations (1)-(3) $[3,5,7,14]$ :

$$
x=\left(x_{/ /}+2 x_{\perp}\right) / 3
$$

where $\chi$ is the magnetic susceptibility and $\chi_{/ /}$and $\chi_{\perp}$ are magnetic susceptibility terms defined as follows:

$$
\begin{gathered}
\chi_{/ /}=\left(N g^{2} \mu_{\mathrm{B}}^{2} / k T\right)\{1+9 \exp (-2 D / k T)\} / 4\{1+\exp (-2 D / k T)\}, \\
\chi_{\perp}=\left(N g^{2} \mu_{\mathrm{B}}^{2} / k T\right)[4+(3 k T / D)\{1-\exp (-2 D / k T)\}] / 4\{1+\exp (-2 D / k T)\} .
\end{gathered}
$$

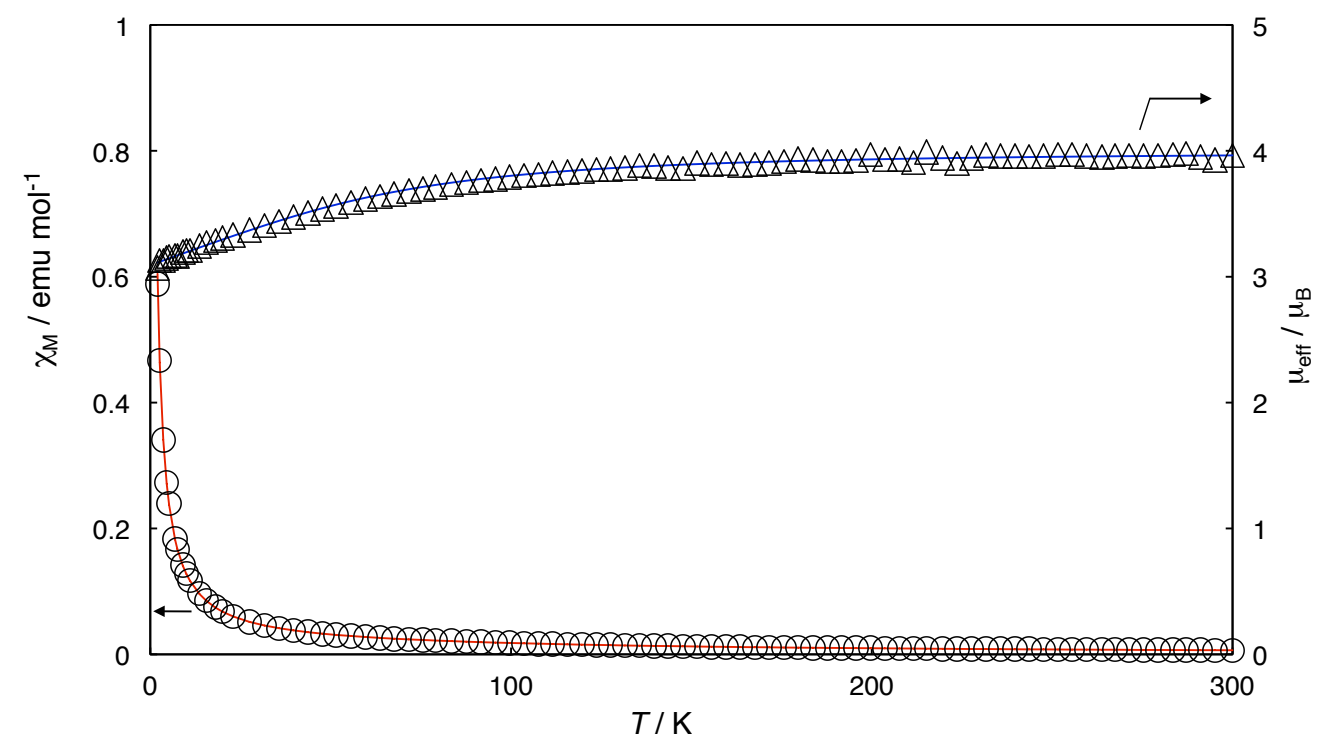

Figure 5. Temperature dependences of magnetic susceptibility $\chi_{\mathrm{M}}$ (circles) and moment $\mu_{\mathrm{eff}}$ (triangles) for $\left[\mathrm{Ru}_{2}\left(\mathrm{O}_{2} \mathrm{CC}_{3} \mathrm{C}_{7}\right)_{4} \mathrm{Cl}\right]_{n}(\mathbf{1})$. The red and blue solid lines were calculated and drawn with the parameter values described in the text. 




Figure 6. Temperature dependences of magnetic susceptibility $\chi_{\mathrm{M}}$ (circles) and moment $\mu_{\mathrm{eff}}$ (triangles) for ${ }^{n} \mathrm{Bu}_{4} \mathrm{~N}\left[\mathrm{Ru}_{2}\left(\mathrm{O}_{2} \mathrm{CC}_{3} \mathrm{C}_{7}\right)_{4} \mathrm{Cl}_{2}\right]$ (2). The red and blue solid lines were calculated and drawn with the parameter values described in the text.

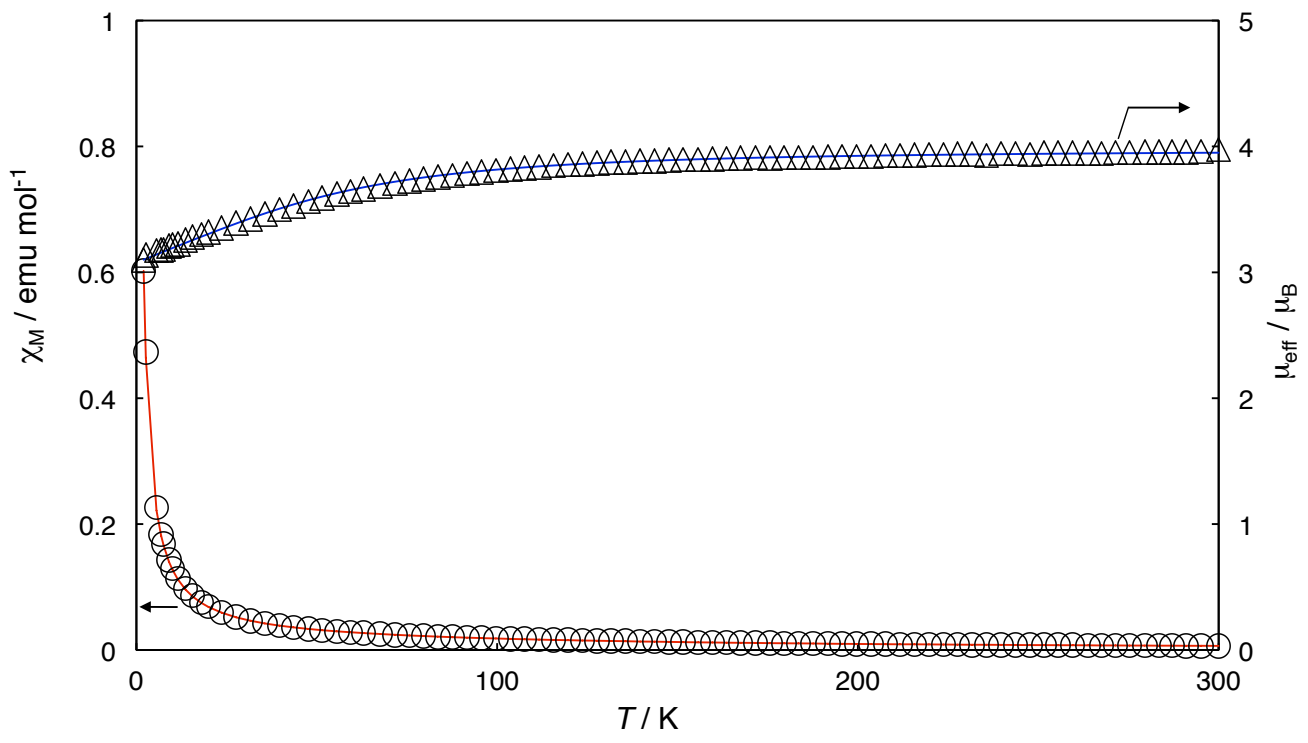

Figure 7. Temperature dependences of magnetic susceptibility $\chi_{\mathrm{M}}$ (circles) and moment $\mu_{\mathrm{eff}}$ (triangles) for $\left[\mathrm{Ru}_{2}\left(\mathrm{O}_{2} \mathrm{CC}_{3} \mathrm{C}_{7}\right)_{4}\left(\mathrm{H}_{2} \mathrm{O}\right)_{2}\right] \mathrm{BF}_{4}(3)$. The red and blue solid lines were calculated and drawn with the parameter values described in the text.

The simulation results provided the following parameter values: $g=2.06, D=68 \mathrm{~cm}^{-1}$ for $1, g=2.08$, $D=78 \mathrm{~cm}^{-1}$ for 2 , and $g=2.05, D=60 \mathrm{~cm}^{-1}$ for 3 . Large $D$ values are common for the lantern-type $\mathrm{Ru}_{2}{ }^{5+}$ complexes [1-5] and are in the range of $D=50-100 \mathrm{~cm}^{-1}$. Although the magnetic interactions between dinuclear units can be estimated using $z J$, which means the exchange energy multiplied by the number of interacting neighboring units and is defined by $\chi^{\prime}=\chi /\left\{1-\left(2 z J / \mathrm{Ng}^{2} \mu_{\mathrm{B}}{ }^{2}\right) \chi\right\}$, when a molecular field approximation is applied $[3,5,7,14]$, the temperature-dependent profiles of magnetic susceptibilities and moments of 1-3 could all be reproduced well without the $z J$ term. That is, the magnetic interactions were negligible for the complexes $\left(z J=0 \mathrm{~cm}^{-1}\right)$. This is reasonable for 2 and 3 because the X-ray crystal structural data showed that the $\mathrm{Ru}_{2}{ }^{5+}$ units were distant from each other without any axial linkers mediating the interaction. As for $\mathbf{1}$, the antiferromagnetic interaction could be possible through an axial chloride linker ligand. The negligible interaction may be due to the zig-zag chain structure with 
a smaller $\mathrm{Ru}-\mathrm{Cl}^{\mathrm{ax}}-\mathrm{Ru}$ bond angle $\left(125.4^{\circ}\right)$. According to an empirical linear relationship between $z J$ and the structural parameter $\mathrm{Ru}-\mathrm{X} / \mathrm{Ru}-\mathrm{X}-\mathrm{Ru}$, which was proposed for lantern-type $\mathrm{Ru}_{2}{ }^{5+}$ complexes with axial halide $\left(\mathrm{X}^{-}\right)$linkers by Delgado-Martinez et al., smaller $\mathrm{Ru}-\mathrm{X}-\mathrm{Ru}$ bond angles decrease the antiferromagnetic interaction [15]. Although the $\mathrm{Ru}-\mathrm{X} / \mathrm{Ru}-\mathrm{X}-\mathrm{Ru}$ value of $\mathbf{1}(2.587 / 125.4=0.0206)$ seems to be for weak antiferromagnetic interaction $\left(z J=-2 \sim-4 \mathrm{~cm}^{-1}\right)$, we expect that the negligible interaction comes from the small $\mathrm{Ru}-\mathrm{Cl}^{\mathrm{ax}}-\mathrm{Ru}$ bond angle $\left(125.4^{\circ}\right)$. A similar explanation has been presented in terms of $\mathrm{MO}$ overlap by Cukiernik et al. for $z J=0 \mathrm{~cm}^{-1}$ of $\left[\mathrm{Ru}_{2}\left(\mathrm{O}_{2} \mathrm{CC}_{3} \mathrm{C}_{7}\right)_{4} \mathrm{Cl}\right]_{n}$ (1) [16]. The magnetic simulation has been reported for 1 as $g_{/ /}=2.02, g_{\perp}=2.14\left(g_{\mathrm{av}}=2.10\right)$, and $D=76.8 \mathrm{~cm}^{-1}$ by Telser et al. as well as $g_{/ /}=2.14, g_{\perp}=2.25\left(g_{\text {av }}=2.21\right)$, and $D=69 \mathrm{~cm}^{-1}$ by Cukiernik et al. Although the $g$ values shown by Cukiernik et al. were rather large, our results for the $g, D$, and $z J$ values obtained in this study for complex 1 were not against the previously reported results.

The EPR spectra measured at $5 \mathrm{~K}$ in solid for $\mathbf{1 - 3}$ are given in Figure 8, Figures S3 and S4. The signal intensities were strong enough for $\mathbf{2}$ and $\mathbf{3}$ to analyze the spectra. Despite the weak signal intensities for $\mathbf{1}$, the $g$ values were barely estimated. The estimated $g$ values were $g_{/ /}=2.040$ and $g_{\perp}=4.390$ for $\mathbf{1} ; g_{/ /}$ $=1.980$ and $g_{\perp}=4.385$ for 2 ; and $g_{/ /}=1.975$ and $g_{\perp}=4.335$ for 3 . For the $S=3 / 2$ system with $D>>g \beta H$, the estimated effective $g$ values $\left(g^{\mathrm{e}}=h v / \beta H\right)$ are $g_{/ /}{ }^{\mathrm{e}} \approx \mathrm{g}_{/ /}$and $\mathrm{g}_{\perp}{ }^{\mathrm{e}} \approx 2 \mathrm{~g}_{\perp}[7,17]$. Thus obtained $g$ values $\left(g_{/ /}=2.040\right.$ and $g_{\perp}=2.195$ for $\mathbf{1} ; g_{/ /}=1.980$ and $g_{\perp}=2.1925$ for $2 ; g_{/ /}=1.975$ and $g_{\perp}=2.168$ for 3) are typical of the lantern-type $\mathrm{Ru}_{2}{ }^{5+}$ complexes $[3,7,8,10,17]$. The axial signal pattern was observed in $1: 1$ toluene $/ \mathrm{CH}_{2} \mathrm{Cl}_{2}$ at $3.4 \mathrm{~K}$ for $\mathbf{1}\left(g_{/ /}=1.9465\right.$ and $\left.g_{\perp}=4.400\right)$ [7].
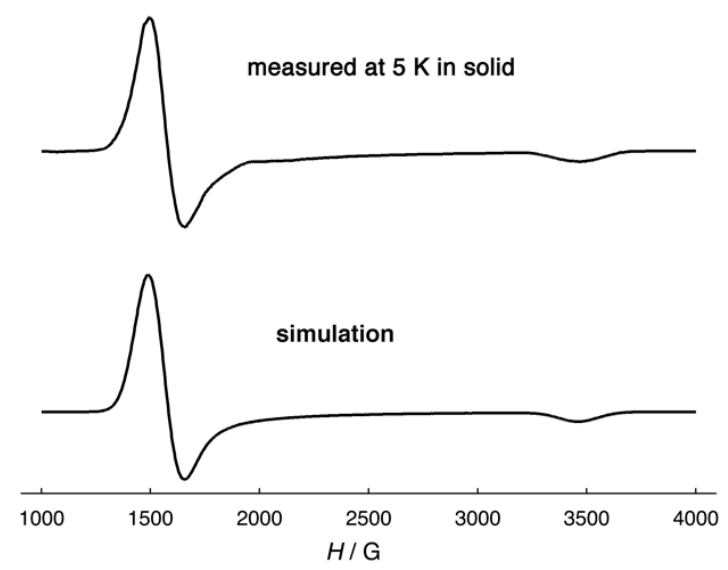

Figure 8. EPR spectra of 2. The simulated spectrum was drawn with the parameter values of $g_{\mathrm{z}}=1.980$, $g_{\mathrm{x}}=g_{\mathrm{y}}=4.385, W_{\mathrm{z}}=120 \mathrm{G}$, and $W_{\mathrm{x}}=W_{\mathrm{y}}=85 \mathrm{G}$.

\subsection{Reflectance and Absorption Spectra}

The diffuse reflectance spectra for the powder samples of 1-3 are given in Figure 9. All of the complexes showed a distinctive band at $430-490 \mathrm{~nm}$ with a discernible shoulder band at 550-690 nm and a broad band at 1030-1150 $\mathrm{nm}$. These spectral features seem to be typical of lantern-type $\mathrm{Ru}_{2}{ }^{5+}$ dinuclear complexes [1]. In fact, $\left[\mathrm{Ru}_{2}\left\{\mathrm{O}_{2} \mathrm{CC}\left(\mathrm{CH}_{3}\right)_{3}\right\}_{4}\right] \mathrm{BF}_{4}$ has been reported as having corresponding bands; a band at $427 \mathrm{~nm}$ with a shoulder band at $545 \mathrm{~nm}$ and a band at $990 \mathrm{~nm}$ in the diffuse reflectance spectrum [18], which were assigned as $\pi\left(\mathrm{Ru}-\mathrm{O}, \mathrm{Ru}_{2}\right) \rightarrow \pi^{*}\left(\mathrm{Ru}_{2}\right), \delta^{*} / \pi^{*}\left(\mathrm{Ru}_{2}\right) \rightarrow \delta^{*}(\mathrm{Ru}-\mathrm{O})$, and $\delta\left(\mathrm{Ru}_{2}\right) \rightarrow \delta^{*}\left(\mathrm{Ru}_{2}\right)$, respectively, according to their assignment in the literature [19]. Absorption spectra (measured in $\mathrm{CH}_{2} \mathrm{Cl}_{2}$ ) are shown in Figure 10. Absorption peaks are found in the near-ultraviolet (450-470 nm) and near-infrared region (1000-1150 nm) for all complexes. The similarity in the spectral features between the reflectance and absorption spectra indicates that the $\mathrm{Ru}_{2}{ }^{5+}$ dinuclear skeletons were maintained in the solution. 


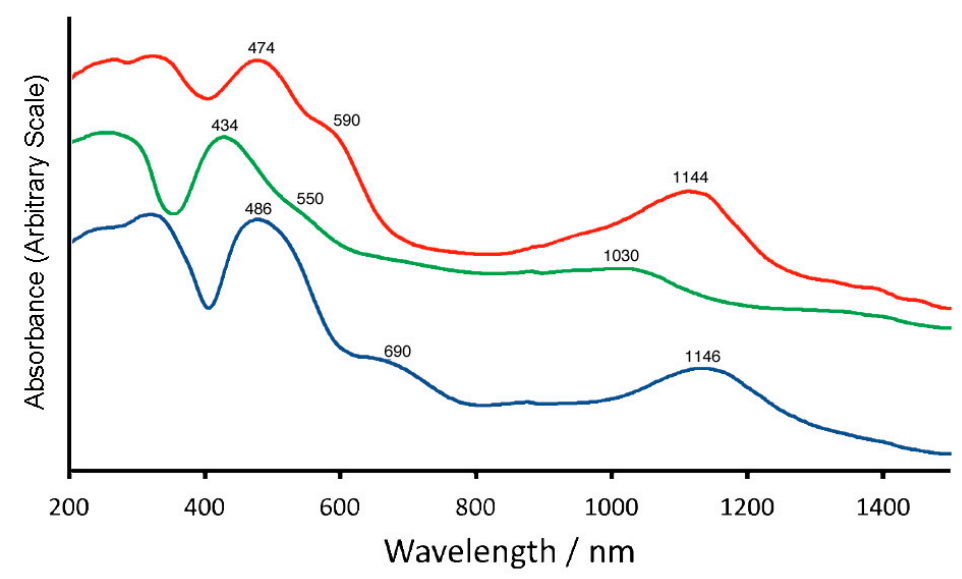

Figure 9. Diffuse reflectance spectra of $\mathbf{1}(-), 2(-)$, and $3(-)$.

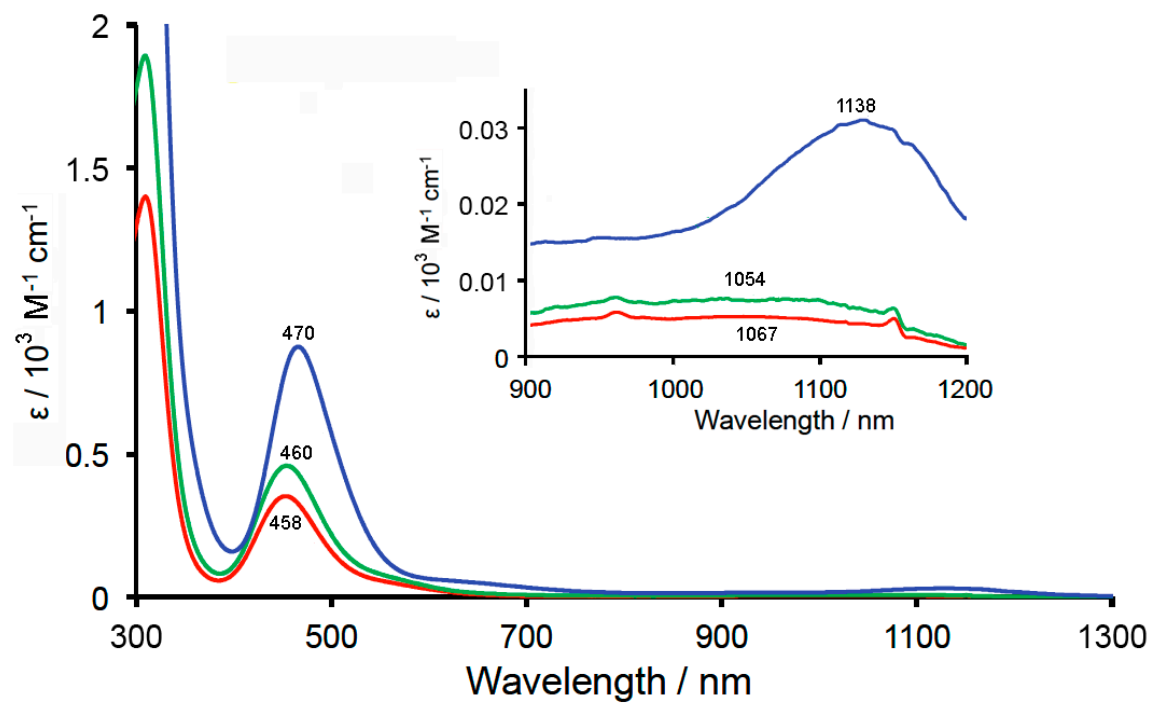

Figure 10. Absorption spectra (measured in $\left.\mathrm{CH}_{2} \mathrm{Cl}_{2}\right)$ of $\mathbf{1}(-), 2(-)$, and $3(-)$.

\subsection{Cyclic Voltammogram (CV)}

Cyclic voltammograms (CVs) were obtained in the dichloromethane solutions containing ${ }^{n} \mathrm{Bu}_{4} \mathrm{~N}\left(\mathrm{BF}_{4}\right)$ (Figure 11). All complexes showed the $\mathrm{Ru}_{2}{ }^{5+} \rightarrow \mathrm{Ru}_{2}{ }^{4+}$ process at $-0.2--0.4 \mathrm{~V}$ and the $\mathrm{Ru}_{2}{ }^{5+} \rightarrow \mathrm{Ru}_{2}{ }^{4+}$ one at 1.3-1.4 V, respectively. Cotton et al. reported that $\left[\mathrm{Ru}_{2}\left(\mathrm{O}_{2} \mathrm{CC}_{3} \mathrm{H}_{7}\right)_{4} \mathrm{Cl}\right]_{n}$ exhibited a two-step $\mathrm{Ru}_{2}{ }^{5+} \rightarrow \mathrm{Ru}_{2}{ }^{4+}$ reduction process $\left(E_{1 / 2}=0.00\right.$ and $-0.34 \mathrm{~V}$ (vs. SCE) in $\mathrm{CH}_{2} \mathrm{Cl}_{2}$ containing $\left.{ }^{n} \mathrm{Bu}_{4} \mathrm{~N}\left(\mathrm{ClO}_{4}\right)\right)$ although a one-step reduction was observed at $E_{1 / 2}=-0.34 \mathrm{~V}$ when ${ }^{n} \mathrm{Bu}_{4} \mathrm{NCl}$ was used as the electrolyte, which was due to the existence of equilibrium shown by $\left[\mathrm{Ru}_{2}\left(\mathrm{O}_{2} \mathrm{CC}_{3} \mathrm{H}_{7}\right)_{4}\right]^{+}+n\left(\mathrm{Cl}^{-}\right) \leftrightarrow\left[\mathrm{Ru}_{2}\left(\mathrm{O}_{2} \mathrm{CC}_{3} \mathrm{H}_{7}\right)_{4} \mathrm{Cl}_{n}\right]^{(n-1)-}$ [8]. It seems reasonable that the bis-adduct species $\left[\mathrm{Ru}_{2}\left(\mathrm{O}_{2} \mathrm{CC}_{3} \mathrm{H}_{7}\right)_{4} \mathrm{Cl}_{2}\right]^{-}$is predominant in the $\mathrm{CH}_{2} \mathrm{Cl}_{2}$ solution containing ${ }^{n} \mathrm{Bu}_{4} \mathrm{NCl}$, and the observed redox couple at $E_{1 / 2}=-0.34 \mathrm{~V}$ can be attributed to that of the $\mathrm{Ru}_{2}{ }^{5+} \rightarrow \mathrm{Ru}_{2}{ }^{4+}$ process of the bis-adduct species. We confirmed that ${ }^{n} \mathrm{Bu}_{4} \mathrm{~N}\left[\mathrm{Ru}_{2}\left(\mathrm{O}_{2} \mathrm{CCH}_{3}\right)_{4} \mathrm{Cl}_{2}\right]$ (4) exhibited a redox couple attributed to the $\mathrm{Ru}_{2}{ }^{5+} \rightarrow \mathrm{Ru}_{2}{ }^{4+}$ process at $E_{1 / 2}=-0.34 \mathrm{~V}$ in a $\mathrm{CH}_{2} \mathrm{Cl}_{2}$ solution with an electrolyte ${ }^{n} \mathrm{Bu}_{4} \mathrm{~N}\left(\mathrm{ClO}_{4}\right)$; in addition, the redox wave observed at $E_{1 / 2}=-0.32 \mathrm{~V}$ for $\left[\mathrm{Ru}_{2}\left(\mathrm{O}_{2} \mathrm{CCH}_{3}\right)_{4} \mathrm{Cl}\right]_{n}$ dissolved in a $\mathrm{CH}_{2} \mathrm{Cl}_{2}$ solution with an electrolyte ${ }^{n} \mathrm{Bu}_{4} \mathrm{NCl}$ [10]. That is, the axial coordination of $\mathrm{Cl}^{-}$to the $\mathrm{Ru}_{2}{ }^{5+}$ unit was kept in the measured $\mathrm{CH}_{2} \mathrm{Cl}_{2}$ solution containing the ${ }^{n} \mathrm{Bu}_{4} \mathrm{~N}\left(\mathrm{ClO}_{4}\right)$ electrolyte. Hence, the axial chloride ligations of 2 could also be considered as kept in the measured $\mathrm{CH}_{2} \mathrm{Cl}_{2}$ solution, although the reversibility of the redox couple $\left(E_{\mathrm{pc}}=-0.46 \mathrm{~V}\right.$ and $\left.E_{\mathrm{pa}}=-0.14 \mathrm{~V}\right)$ was not good when compared with that of $4\left(E_{\mathrm{pc}}=-0.40 \mathrm{~V}\right.$ and $\left.E_{\mathrm{pa}}=-0.28 \mathrm{~V}\right)$ [10]. We performed DFT calculations to estimate the redox potentials $\left(E^{\text {calc }}{ }_{1 / 2}\right)$ for $\mathrm{Ru}_{2}{ }^{5+} \rightarrow \mathrm{Ru}_{2}{ }^{4+}$ as well as the $\mathrm{Ru}_{2}{ }^{6+} \rightarrow \mathrm{Ru}_{2}{ }^{5+}$ 
processes for $\left[\mathrm{Ru}_{2}\left(\mathrm{O}_{2} \mathrm{CC}_{3} \mathrm{H}_{7}\right)_{4} \mathrm{Cl}_{2}\right]^{-}$by using our previous treatment for $\left[\mathrm{Ru}_{2}\left(\mathrm{O}_{2} \mathrm{CCH}_{3}\right)_{4} \mathrm{Cl}_{2}\right]^{-}$[10]. The calculated values were $E^{\text {calc }}{ }_{1 / 2}\left(\right.$ for $\left.\mathrm{Ru}_{2}{ }^{5+} \rightarrow \mathrm{Ru}_{2}{ }^{4+}\right)=-0.42 \mathrm{~V}$ and $E^{\text {calc }}{ }_{1 / 2}\left(\right.$ for $\mathrm{Ru}_{2}{ }^{6+} \rightarrow \mathrm{Ru}_{2}{ }^{5+}$ ) $=1.25 \mathrm{~V}$. The results support the assignment of the $\mathrm{Ru}_{2}{ }^{5+} \rightarrow \mathrm{Ru}_{2}{ }^{4+}$ process at $-0.2--0.4 \mathrm{~V}$ and the $\mathrm{Ru}_{2}{ }^{6+} \rightarrow \mathrm{Ru}_{2}{ }^{5+}$ one at 1.3-1.4 V for 2. We further performed calculations on $\left[\mathrm{Ru}_{2}\left(\mathrm{O}_{2} \mathrm{CC}_{3} \mathrm{H}_{7}\right)_{4} \mathrm{Cl}\right]$ and $\left[\mathrm{Ru}_{2}\left(\mathrm{O}_{2} \mathrm{CC}_{3} \mathrm{H}_{7}\right)_{4}\left(\mathrm{H}_{2} \mathrm{O}\right)_{2}\right]^{+}$as the model compounds of $\mathbf{1}$ and 3, respectively. The calculated $E^{\text {calc }}{ }_{1 / 2}$ (for $\mathrm{Ru}_{2}{ }^{5+} \rightarrow \mathrm{Ru}_{2}{ }^{4+}$ ) and $E^{\text {calc }}{ }_{1 / 2}\left(\right.$ for $\mathrm{Ru}_{2}{ }^{6+} \rightarrow \mathrm{Ru}_{2}{ }^{5+}$ ) values were -0.05 and $2.09 \mathrm{~V}$ for $\left[\mathrm{Ru}_{2}\left(\mathrm{O}_{2} \mathrm{CC}_{3} \mathrm{H}_{7}\right)_{4} \mathrm{Cl}\right]$, and 0.34 and $2.77 \mathrm{~V}$ for $\left[\mathrm{Ru}_{2}\left(\mathrm{O}_{2} \mathrm{CC}_{3} \mathrm{H}_{7}\right)_{4}\left(\mathrm{H}_{2} \mathrm{O}\right)_{2}\right]^{+}$. At present, it is difficult to explain the reason why complexes 1-3 showed redox waves at similar potentials of $-0.2--0.4 \mathrm{~V}$ and 1.3-1.4 V. Many factors such as the coordination of the $\mathrm{Cl}^{-}$ion and $\mathrm{BF}_{4}{ }^{-}$ion of the electrolyte ${ }^{n} \mathrm{Bu}_{4} \mathrm{~N}\left(\mathrm{BF}_{4}\right)$ as well as the oligomerization of $\mathrm{Ru}_{2}{ }^{5+}$ dinuclear units should be taken further into consideration.

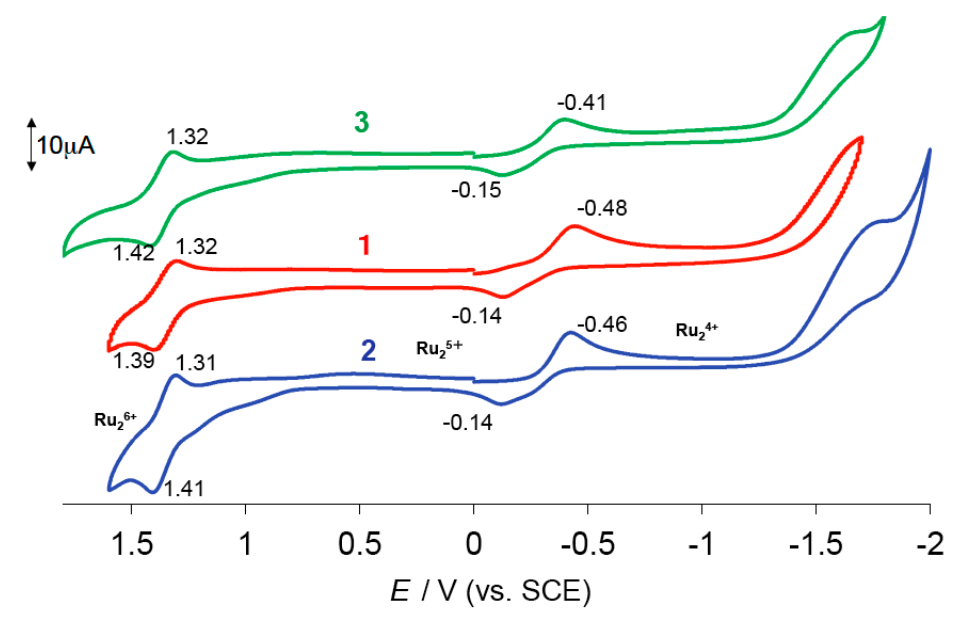

Figure 11. Cyclic voltammograms of 1-3 at $1.0 \times 10^{-3} \mathrm{M}$ in $\mathrm{CH}_{2} \mathrm{Cl}_{2}$ containing $0.1 \mathrm{M} \mathrm{TBA}(\mathrm{BF})_{4}$ (glassy carbon working electrode; scan rate $=50 \mathrm{mV} / \mathrm{s}$ ).

\section{Materials and Methods}

\subsection{General Aspects}

All reagents and solvents were used as received. The complex $\left[\mathrm{Ru}_{2}\left(\mathrm{O}_{2} \mathrm{CC}_{3} \mathrm{H}_{7}\right)_{4} \mathrm{Cl}\right]_{n}(\mathbf{1})$ was prepared according to a published procedure [8].

Elemental analyses for carbon, hydrogen, and nitrogen were performed using a Yanako CHN Corder MT-6. Infrared spectra (KBr pellets) were measured with a JASCO FT/IR-4600. Absorption spectra and diffuse reflectance spectra were obtained using JASCO V-670 and Shimadzu UV-3100 spectrometers, respectively. The temperature dependent magnetic susceptibilities were measured over the temperature range of $2-300 \mathrm{~K}$ at the constant field of $0.5 \mathrm{~T}$ with a Quantum Design MPMS XL-5. The measured data were corrected for diamagnetic contributions [20]. EPR spectra were measured at $5 \mathrm{~K}$ in solid by a BRUKER ELEXSYS E500 equipped with OXFORD ESR900 and OXFORD ITC503 attachments. The EPR simulation was conducted using the "Hyperfine Spectrum" program with spin Hamiltonian, $\boldsymbol{H}_{\mathrm{s}}=\beta B \bullet \mathrm{g} S$ [21]. Cyclic voltammograms (CVs) were measured in dichloromethane containing ${ }^{n} \mathrm{Bu}_{4} \mathrm{~N}\left(\mathrm{BF}_{4}\right)$ on a BAS ALS-DY2325 electrochemical analyzer. A glassy carbon disk (1.5 $\mathrm{mm}$ radius), platinum wire, and saturated calomel electrodes were used as the working, counter, and reference electrodes, respectively. All of the potential values are described versus SCE. 


\subsection{Syntheses of Complexes}

\subsubsection{Synthesis of ${ }^{\mathrm{n}} \mathrm{Bu}_{4} \mathrm{~N}\left[\mathrm{Ru}_{2}\left(\mathrm{O}_{2} \mathrm{CC}_{3} \mathrm{H}_{7}\right)_{4} \mathrm{Cl}_{2}\right]$ (2)}

A suspension of $\left[\mathrm{Ru}_{2}\left(\mathrm{O}_{2} \mathrm{CC}_{3} \mathrm{H}_{7}\right)_{4} \mathrm{Cl}\right]_{n}\left(50 \mathrm{mg}, 0.085 \mathrm{mmol}\right.$ (based on $\mathrm{Ru}_{2}$ dinuclear unit)) was stirred with ${ }^{n} \mathrm{Bu}_{4} \mathrm{NCl}(29.5 \mathrm{mg}, 0.11 \mathrm{mmol})$ in dichloromethane $(20 \mathrm{~mL})$ for $24 \mathrm{~h}$ at room temperature. The resulting solution was concentrated to a small portion and stood to give a brown precipitation, which was collected by suction and dried under vacuum overnight. The yield was $62.9 \mathrm{mg}(85 \%$ based on $\left[\mathrm{Ru}_{2}\left(\mathrm{O}_{2} \mathrm{CC}_{3} \mathrm{H}_{7}\right)_{4} \mathrm{Cl}\right]$ unit). Anal. Found: $\mathrm{C}, 44.93 ; \mathrm{H}, 7.38 ; \mathrm{N}, 2.00 \%$. Cacld. for $\mathrm{C}_{32} \mathrm{H}_{64} \mathrm{Cl}_{2} \mathrm{NO}_{8} \mathrm{Ru}_{2}$, C, 44.49, H, 7.47; N, 1.62\%. IR (KBr disk, cm ${ }^{-1}$ ): 2964 s, 2936 m, 2874 m, 1465 s, 1426 vs, 1313 m, 1261 w, $1200 \mathrm{vw}, 1172 \mathrm{vw}, 1102 \mathrm{vw}, 889 \mathrm{w}, 798 \mathrm{w}, 729 \mathrm{w}, 677 \mathrm{w}, 628 \mathrm{w}$, and $461 \mathrm{~m}$.

\subsubsection{Synthesis of $\left[\mathrm{Ru}_{2}\left(\mathrm{O}_{2} \mathrm{CC}_{3} \mathrm{H}_{7}\right)_{4}\left(\mathrm{H}_{2} \mathrm{O}\right)_{2}\right] \mathrm{BF}_{4}(3)$}

A suspension of $\left[\mathrm{Ru}_{2}\left(\mathrm{O}_{2} \mathrm{CC}_{3} \mathrm{H}_{7}\right)_{4} \mathrm{Cl}\right]_{n}\left(90.9 \mathrm{mg}, 0.15 \mathrm{mmol}\right.$ (based on $\mathrm{Ru}_{2}$ dinuclear unit)) was stirred with $\mathrm{AgBF}_{4}(31.1 \mathrm{mg}, 0.16 \mathrm{mmol})$ in THF $(20 \mathrm{~mL})$ for $24 \mathrm{~h}$ at room temperature, and the reaction vessel was covered with aluminum foil to shield against the light. The precipitate of $\mathrm{AgCl}$ was removed by filtration through celite. The filtrate solution was concentrated to a small portion by evaporating under reduced pressure and stood overnight to give a brown microcrsytalline solid, which was separated by filtration, washed with hexane, and dried under vacuum overnight. The yield was $71.8 \mathrm{mg}\left(69 \%\right.$ based on $\left[\mathrm{Ru}_{2}\left(\mathrm{O}_{2} \mathrm{CC}_{3} \mathrm{H}_{7}\right)_{4} \mathrm{Cl}\right]$ unit). Anal. Found: $\mathrm{C}, 28.33 ; \mathrm{H}, 4.41 \%$. Cacld. for $\mathrm{C}_{16} \mathrm{H}_{32} \mathrm{BF}_{4} \mathrm{O}_{10} \mathrm{Ru}_{2}, \mathrm{C}, 28.54, \mathrm{H}, 4.79 \%$. IR (KBr disk, cm $\left.{ }^{-1}\right): 2965 \mathrm{~s}, 2932 \mathrm{~m}, 2878 \mathrm{~m}, 1455 \mathrm{vs}, 1428 \mathrm{vs,}$ $1320 \mathrm{~m}, 1266 \mathrm{w}, 1213 \mathrm{w}, 1090 \mathrm{vs}, 801 \mathrm{w}, 739 \mathrm{~m}, 673 \mathrm{~m}, 525 \mathrm{vw}$, and $465 \mathrm{~m}$.

\subsection{Crystal Structure Determination}

Single crystals of 2 and 3 suitable for X-ray crystal structure analysis were obtained by the recrystallization from dichloromethane-diethyl ether and dichloromethane-benzene mixed solvents, respectively. X-ray crystallographic data (Table 1) were collected for a single crystal at $90 \mathrm{~K}$ on a Bruker CCD X-ray diffractometer (SMART APEX) using graphite-monochromated Mo K $\alpha$ radiation $(\lambda=0.71073 \AA$ ) for 2 and a RIGAKU Saturn 724 CCD system equipped with a Mo rotating-anode X-ray generator with monochromated Mo K $\alpha$ radiation $(\lambda=0.71075 \AA)$ for 3 . Diffraction data of 2 and 3 were processed using APEX2 (Bruker) and CrystalClear-SM (RIGAKU), respectively. The structures of 2 and 3 were solved by intrinsic phasing methods (SHELEX) and direct methods (SIR-2011), respectively and refined using the full-matrix least-squares technique $\left(\mathrm{F}^{2}\right)$ with SHELXL-2014 as part of the SAINT (Bruker) (Billerica, MS, USA) and CrystalStructure 4.2.5 (RIGAKU) (Tokyo, Japan) software, respectively. Non-hydrogen atoms were refined with anisotropic displacement parameters, and all hydrogen atoms were refined with a riding model. Selected bond distances and angles for 2 and 3 are given in Tables S1 and S2, respectively.

CCDC-1887475 and 1887753 contain the supplementary crystallographic data for ${ }^{n} \mathrm{Bu}_{4} \mathrm{~N}\left[\mathrm{Ru}_{2}\left(\mathrm{O}_{2} \mathrm{CC}_{3} \mathrm{H}_{7}\right)_{4} \mathrm{Cl}_{2}\right]$ (2) and $\left[\mathrm{Ru}_{2}\left(\mathrm{O}_{2} \mathrm{CC}_{3} \mathrm{H}_{7}\right)_{4}\left(\mathrm{H}_{2} \mathrm{O}\right)_{2}\right] \mathrm{BF}_{4}$ (3), respectively. These data can be obtained free of charge from the Cambridge Crystallographic Data Centre [22]. 
Table 1. Crystallographic data of ${ }^{n} \mathrm{Bu}_{4} \mathrm{~N}\left[\mathrm{Ru}_{2}\left(\mathrm{O}_{2} \mathrm{CC}_{3} \mathrm{H}_{7}\right)_{4} \mathrm{Cl}_{2}\right](2)$ and $\left[\mathrm{Ru}_{2}\left(\mathrm{O}_{2} \mathrm{CC}_{3} \mathrm{H}_{7}\right)_{4}\left(\mathrm{H}_{2} \mathrm{O}\right)_{2}\right] \mathrm{BF}_{4}(3)^{\mathrm{a}}$.

\begin{tabular}{|c|c|c|}
\hline & 2 & 3 \\
\hline Empirical formula & $\mathrm{C}_{32} \mathrm{H}_{64} \mathrm{Cl}_{2} \mathrm{NO}_{8} \mathrm{Ru}_{2}$ & $\mathrm{C}_{16} \mathrm{H}_{32} \mathrm{BF}_{4} \mathrm{O}_{10} \mathrm{Ru}_{2}$ \\
\hline Formula mass & 863.88 & 673.37 \\
\hline Temperature & $90 \mathrm{~K}$ & $90 \mathrm{~K}$ \\
\hline Crystal system & Triclinic & Monoclinic \\
\hline Space group & $P \overline{1}$ & $P 2 / c$ \\
\hline$a$ & $16.0297(11) \AA$ & $12.600(4) \AA$ \\
\hline$b$ & $16.0936(11) \AA$ & 8.808(3) $\AA$ \\
\hline$c$ & $18.6813(13) \AA$ & $13.968(4) \AA$ \\
\hline$\alpha$ & $68.4640(10)^{\circ}$ & $90^{\circ}$ \\
\hline$\beta$ & $68.5090(10)^{\circ}$ & $106.581(4)^{\circ}$ \\
\hline$\gamma$ & $64.3420(10)^{\circ}$ & $90^{\circ}$ \\
\hline Unit-cell volume, $V$ & $3915.3(5) \AA^{3}$ & $1485.7(8) \AA^{3}$ \\
\hline Formula per unit cell, $Z$ & 4 & 2 \\
\hline Density, $D_{\text {calcd }}$ & $1.466 \mathrm{~g} \mathrm{~cm}^{-3}$ & $1.505 \mathrm{~g} \mathrm{~cm}^{-3}$ \\
\hline Crystal size & $0.330 \times 0.300 \times 0.200 \mathrm{~mm}^{3}$ & $0.300 \times 0.160 \times 0.060 \mathrm{~mm}^{3}$ \\
\hline Absorption coefficient, $\mu$ & $0.953 \mathrm{~mm}^{-1}$ & $1.080 \mathrm{~mm}^{-1}$ \\
\hline$\theta$ range for data collection & $1.641-28.500^{\circ}$ & $2.768-24.496^{\circ}$ \\
\hline Reflections collected/unique & $25828 / 18244$ & $8821 / 2430$ \\
\hline $\mathrm{R}$ indices $[\mathrm{I}>2 \sigma(I)]^{\mathrm{b}}$ & $R_{1}=0.0348, w R_{2}=0.0867$ & $R_{1}=0.0265, w R_{2}=0.0783$ \\
\hline Goodness-of-fit on $\mathrm{F}^{2}$ & 1.072 & 1.164 \\
\hline
\end{tabular}

\subsection{Computational Details}

The unrestricted density functional theory (uDFT) calculations applied in this study were performed with the long-range and dispersion correlated hybrid DFT functional method, $\omega$ B97XD, on the Gaussian 09 program [23]. The Los Alamos effective core potential LANL08(f) and Pople's 6-311 $+\mathrm{G}^{*}$ basis sets were applied for the Ru and other atoms, respectively. All molecular geometries were fully optimized and checked by the vibrational frequency analyses. The solvent effect of $\mathrm{CH}_{2} \mathrm{Cl}_{2}$ was considered by the polarizable continuum model (PCM). The redox potentials were estimated by using the standard method with the Born-Harbor cycle and Gibbs free energy changes, which was defined by Noodleman [24]. In order to estimate the redox potentials $\left(E^{\mathrm{calc}}{ }_{1 / 2}\right)$ for the $\mathrm{Ru}_{2}{ }^{5+} \rightarrow$ $\mathrm{Ru}_{2}{ }^{4+}$ and $\mathrm{Ru}_{2}{ }^{6+} \rightarrow \mathrm{Ru}_{2}{ }^{5+}$ processes, the atomic coordinates of optimized geometries for $\mathrm{Ru}_{2}{ }^{4+}, \mathrm{Ru}_{2}{ }^{5+}$, and $\mathrm{Ru}_{2}{ }^{6+}$ species are needed for $\left[\mathrm{Ru}_{2}\left(\mathrm{O}_{2} \mathrm{CC}_{3} \mathrm{H}_{7}\right)_{4} \mathrm{Cl}\right]$ (model compound of $\mathbf{1}$ ), $\left[\mathrm{Ru}_{2}\left(\mathrm{O}_{2} \mathrm{CC}_{3} \mathrm{H}_{7}\right)_{4} \mathrm{Cl}_{2}\right]^{-}$ (model compound of 2), and $\left[\mathrm{Ru}_{2}\left(\mathrm{O}_{2} \mathrm{CC}_{3} \mathrm{H}_{7}\right)_{4}\left(\mathrm{H}_{2} \mathrm{O}\right)_{2}\right]^{+}$(model compound of 3 ), respectively. All of the coordinates used for the estimations are given in Tables S3-S11. We subtracted 4.68 V (IUPAC value) [25] from the calculated absolute potentials of the $\mathrm{Ru}_{2}$ complexes to make a direct comparison to the experimental CV data referenced to the SCE.

\section{Conclusions}

By using $\left[\mathrm{Ru}_{2}\left(\mathrm{O}_{2} \mathrm{CC}_{3} \mathrm{H}_{7}\right)_{4} \mathrm{Cl}\right]_{n}$ as a starting material, ${ }^{n} \mathrm{Bu}_{4} \mathrm{~N}\left[\mathrm{Ru}_{2}\left(\mathrm{O}_{2} \mathrm{CC}_{3} \mathrm{H}_{7}\right)_{4} \mathrm{Cl}_{2}\right]$ and $\left[\mathrm{Ru}_{2}\left(\mathrm{O}_{2} \mathrm{CC}_{3} \mathrm{H}_{7}\right)_{4}\left(\mathrm{H}_{2} \mathrm{O}\right)_{2}\right] \mathrm{BF}_{4}$ were prepared. Their lantern-type dinuclear structures with axial ligands of $\mathrm{Cl}^{-}$or $\mathrm{H}_{2} \mathrm{O}$ were confirmed by $\mathrm{X}$-ray crystal structure analyses. Temperature dependent magnetic susceptibility measurements were performed to show that all of the complexes $\left(\left[\mathrm{Ru}_{2}\left(\mathrm{O}_{2} \mathrm{CC}_{3} \mathrm{H}_{7}\right)_{4} \mathrm{Cl}\right]_{n}\right.$, ${ }^{n} \mathrm{Bu}_{4} \mathrm{~N}\left[\mathrm{Ru}_{2}\left(\mathrm{O}_{2} \mathrm{CC}_{3} \mathrm{H}_{7}\right)_{4} \mathrm{Cl}_{2}\right]$, and $\left.\left[\mathrm{Ru}_{2}\left(\mathrm{O}_{2} \mathrm{CC}_{3} \mathrm{H}_{7}\right)_{4}\left(\mathrm{H}_{2} \mathrm{O}\right)_{2}\right] \mathrm{BF}_{4}\right)$ had an $\mathrm{S}=3 / 2$ ground state, with a large zero-field splitting $\left(D=60-80 \mathrm{~cm}^{-1}\right)$. No important magnetic interaction was observed between the dinuclear units for the complexes. Cyclic voltammograms (measured in $\mathrm{CH}_{2} \mathrm{Cl}_{2}$ with an electrolyte of ${ }^{n} \mathrm{Bu}_{4} \mathrm{~N}\left(\mathrm{BF}_{4}\right)$ ) showed the $\mathrm{Ru}_{2}{ }^{5+} / \mathrm{Ru}_{2}{ }^{4+}$ process at $-0.2--0.4 \mathrm{~V}$ (vs. SCE) and the $\mathrm{Ru}_{2}{ }^{6+} / \mathrm{Ru}_{2}{ }^{5+}$ one at 1.3-1.4 V (vs. SCE), where the potentials were confirmed by the DFT calculation for $\left[\mathrm{Ru}_{2}\left(\mathrm{O}_{2} \mathrm{CC}_{3} \mathrm{H}_{7}\right)_{4} \mathrm{Cl}_{2}\right]^{-}$. 
Supplementary Materials: The following are available at http://www.mdpi.com/2312-7481/5/1/18/s1. Selected bond distances and angles of 2 (Table S1); selected bond distances and angles of 3 (Table S2); atomic coordinates of optimized geometries of $\mathrm{Ru}_{2}{ }^{4+}, \mathrm{Ru}_{2}{ }^{5+}$, and $\mathrm{Ru}_{2}{ }^{6+}$ species for $\left[\mathrm{Ru}_{2}\left(\mathrm{O}_{2} \mathrm{CC}_{3} \mathrm{H}_{7}\right)_{4} \mathrm{Cl}\right.$, $\left[\mathrm{Ru}_{2}\left(\mathrm{O}_{2} \mathrm{CC}_{3} \mathrm{H}_{7}\right)_{4} \mathrm{Cl}_{2}\right]^{-}$, and $\left[\mathrm{Ru}_{2}\left(\mathrm{O}_{2} \mathrm{CC}_{3} \mathrm{H}_{7}\right)_{4}\left(\mathrm{H}_{2} \mathrm{O}\right)_{2}\right]+$ (Tables S3-S11); structure of an anionic dinuclear unit designated as (Cl3-Ru3- $\left.\mathrm{Ru}^{\prime \prime}-\mathrm{Cl}^{\prime \prime}\right)$ (Figure S1); structure of an anionic dinuclear unit designated as $\left(\mathrm{Cl} 4-\mathrm{Ru} 4-\mathrm{Ru} 4^{\prime \prime \prime}-\mathrm{Cl}^{\prime \prime \prime}\right.$ ) (Figure S2); EPR spectra of $\mathbf{1}$ (Figure S3); and EPR spectra of 3 (Figure S4).

Author Contributions: M.H. conceived and designed the experiment, analyzed the data, and wrote the paper; H.Y. and N.Y. performed the experiments. M.M. (Minoru Mitsumi) and H.A. helped with the SQUID measurements and x-ray crystal structure determination. H.S. analyzed the magnetic susceptibility and EPR data. M.K. and I.I. measured the EPR spectra. R.M. determined the X-ray crystal structure of 2. M.M. (Masahiro Mikuriya) measured the diffuse reflectance spectra. Y.K. measured SQUID, determined the x-ray crystal structure of 3, performed DFT calculations, and wrote the part of the DFT calculation results in the paper.

Funding: The present work was partially supported by Grants-in-Aid for Scientific Research Nos. 15K17897, 16K05722, and 17K05820 from the Ministry of Education, Culture, Sports, Science and Technology (MEXT), Japan.

Acknowledgments: Y. Yano acknowledges the Research Fellowships of the Japan Society for the Promotion of Science for Young Scientists. The authors are grateful to Michiko Egawa (Shimane University) for her measurements of the elemental analyses.

Conflicts of Interest: The authors declare no conflict of interest.

\section{References}

1. Cotton, F.A.; Murillo, C.A.; Walton, R.A. Multiple Bonds between Metal Atoms, 3rd ed.; Springer: New York, NY, USA, 2005.

2. Liddle, S.T. Molecular Metal-Metal Bonds, Compounds, Synthesis, Properties; Wiley-VCH: Weinheim, Germany, 2015.

3. Aquino, M.A.S. Diruthenium and diosmium tetracarboxylates: Synthesis, physical properties and applications. Coord. Chem. Rev. 1998, 170, 141-202. [CrossRef]

4. Aquino, M.A.S. Recent developments in the synthesis and properties of diruthnium tetracarboxylates. Coord. Chem. Rev. 2004, 248, 1025-1045. [CrossRef]

5. Mikuriya, M.; Yoshioka, D.; Handa, M. Magnetic interactions in one-, two-, and three-dimensional assemblies of dinuclear ruthenium carboxylates. Coord. Chem. Rev. 2006, 250, 2194-2211. [CrossRef]

6. Bennett, M.J.; Caulton, K.G.; Cotton, F.A. The structure of tetra-n-butyratodiruthenium chloride, a compound with a strong metal-metal bond. Inorg. Chem. 1969, 8, 1-6. [CrossRef]

7. Telser, J.; Drago, R.S. Reinvesigation of the Electronic and Magnetic Properties of Ruthenium Butyrate Chloride. Inorg. Chem. 1984, 23, 3114-3120, Erratum in 1985, 24, 4765, doi:10.1021/ic00220a601. [CrossRef]

8. Cotton, F.A.; Pedersen, E. Magnetic and electrochemical properties of transition metal complexes with multiple metal-to-metal bonds. II. $\left[\mathrm{Ru}_{2}\left(\mathrm{C}_{3} \mathrm{H}_{7} \mathrm{COO}\right)_{4}\right]^{n+}$ with $\mathrm{n}=0$ and 1. Inorg. Chem. 1975, 14, 388-391. [CrossRef]

9. Nakamoto, K. Infrared and Raman Spectra, 4th ed.; John Wiley \& Sons: New York, NY, USA, 1986.

10. Hiraoka, Y.; Ikeue, T.; Sakiyama, H.; Guégan, F.; Luneau, D.; Gillon, B.; Hiromitsu, I.; Yoshioka, D.; Mikuriya, M.; Kataoka, Y.; et al. An unprecedented up-field shift in the ${ }^{13} \mathrm{C}$ NMR spectrum of the carboxyl carbons of the lantern-type dinuclear complex TBA $\left[\mathrm{Ru}_{2}\left(\mathrm{O}_{2} \mathrm{CCH}_{3}\right)_{4} \mathrm{Cl}_{2}\right]\left(\mathrm{TBA}^{+}=\right.$tetra(n-butyl)ammonium cation. Dalton Trans. 2015, 44, 13439-13443. [CrossRef] [PubMed]

11. Bino, A.; Cotton, F.A.; Felthouse, T.R. Structural studies of some multiply bonded diruthenium tetracarboxylate compounds. Inorg. Chem. 1979, 18, 2599-2604. [CrossRef]

12. Drysdale, K.D.; Beck, E.J.; Cameron, T.S.; Robertson, K.N.; Aquino, M.A.S. Crystal structures and physico-chemical properties of a series of $\left[\mathrm{Ru}_{2}\left(\mathrm{O}_{2} \mathrm{CCH}_{3}\right)_{4} \mathrm{~L}_{2}\right]\left(\mathrm{PF}_{6}\right)$ adducts $\left(\mathrm{L}=\mathrm{H}_{2} \mathrm{O}\right.$, DMF, DMSO). Inorg. Chim. Acta 1997, 256, 243-252. [CrossRef]

13. Sayama, Y.; Handa, M.; Nukada, R.; Hiromitsu, I.; Kasuga, K. Mixed-Valent Ruthenium Pivalate and Its Nitroxide Adduct. In Coordination Chemistry at the Turn of The Chemistry; Ondrejovic, G., Sirota, A., Eds.; Slovak Technical Universty Press: Bratislava, Slovakia, 1999; pp. 447-452.

14. O'Connor, C.J. Magnetochemistry-Advances in Theory and Experimentaion. Prog. Inorg. Chem. 1982, 29, 203-283. [CrossRef] 
15. Delgado-Martinez, P.; González-Prieto, R.; Gómez-García, C.J.; Jiménez-Aparicio, R.; Priego, J.L.; Torres, M.R. Structural, magnetic and electrical properties of one-dimensional tetraamidatodiruthnium compounds. Dalton Trans. 2014, 43, 3227-3237. [CrossRef] [PubMed]

16. Cukiernik, F.D.; Luneau, D.; Machon, J.-C.; Maldivi, P. Mixed-Valent Diruthenium Long-Chain Carboxylates. 2. Magnetic Properties. Inorg. Chem. 1998, 37, 3698-3704. [CrossRef] [PubMed]

17. Handa, M.; Sayama, Y.; Mikuriya, M.; Nukada, R.; Hiromitsu, I.; Kasuga, K. Structure and Magnetic Properties of a Nitroxide Diruthenium(II,III) Complex, $\left[\mathrm{Ru}_{2}\left(\mathrm{O}_{2} \mathrm{CCMe}_{3}\right)_{4}(\mathrm{tempo})_{2}\right]\left[\mathrm{Ru}_{2}\left(\mathrm{O}_{2} \mathrm{CCMe}_{3}\right)_{4}\left(\mathrm{H}_{2} \mathrm{O}\right)_{2}\right]$ $\left(\mathrm{BF}_{4}\right)_{2}$ (tempo = 2,2,6,6-Tetramethylpiperidine-1-oxyl). Bull. Chem. Soc. Jpn. 1995, 68, 1647-1653. [CrossRef]

18. Yoshioka, D.; Mikuirya, M.; Handa, M. Synthsis and Characterization of Polynuclear Chain and Tetranuclear Complexes of Mixed-Valent Ruthenium(II,III) Pivalate with $N, N^{\prime}$-Didentate Ligands. Bull. Chem. Soc. Jpn. 2004, 77, 2205-2211. [CrossRef]

19. Miskowski, V.M.; Gray, H.B. Electronic spectra of $\mathrm{Ru}_{2}$ (carboxylate) ${ }^{4+}$ complexes. Higher energy electronic excited states. Inorg. Chem. 1988, 27, 2501-2506. [CrossRef]

20. Kahn, O. Molecular Magnetism; VCH: Cambridge, UK, 1993; Chapter 1.

21. Hagen, W.R. Biomolecular EPR Spectroscopy; CRC: Boca Raton, FL, USA, 2009.

22. Access Structures. Available online: www.ccdc.cam.ac.uk/data_request/cif (accessed on 5 March 2019).

23. Frisch, M.J.; Trucks, G.W.; Schlegel, H.B.; Scuseria, G.E.; Robb, M.A.; Cheeseman, J.R.; Scalmani, G.; Barone, V.; Mennucci, B.; Petersson, G.A.; et al. Gaussian 09, Revision C.01; Gaussian, Inc.: Wallingford, CT, USA, 2009.

24. Li, J.; Fisher, C.L.; Chen, J.L.; Bashford, D.; Noodleman, L. Calculation of Redox Potentials and pKa Values of Hydrated Transition Metal Cations by a Combined Density Functional and Continuum Dielectric Theory. Inorg. Chem. 1996, 35, 4694-4702. [CrossRef]

25. Trasatti, S. The Absolute Electrode Potential: An Explanatory Note. Pure Appl. Chem. 1986, 58, $955-966$. [CrossRef]

(C) 2019 by the authors. Licensee MDPI, Basel, Switzerland. This article is an open access article distributed under the terms and conditions of the Creative Commons Attribution (CC BY) license (http:// creativecommons.org/licenses/by/4.0/). 